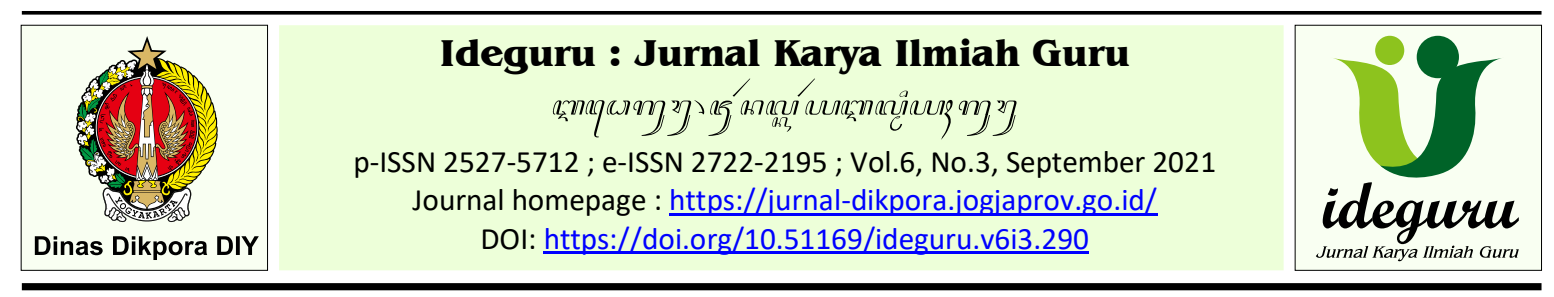

Artikel Penelitian - Naskah dikirim: 23/05/2021 - Selesai revisi: 02/08/2021 - Disetujui: 03/08/2021 - Diterbitkan: 01/09/2021

\title{
Penerapan Model Pembelajaran Self Organized Learning Environments (SOLE) untuk Meningkatkan Pemahaman Materi Polimer
}

\author{
Sri Suciati \\ SMK Negeri 1 Sanden \\ 0967.srisuciati@gmail.com
}

\begin{abstract}
Abstrak: Penelitian ini bertujuan untuk: 1) mengetahui deskripsi penerapan model pembelajaran self organized learning environments (SOLE) pada materi polimer untuk siswa kelas X RPL di SMK N 1 Sanden, 2) menguji peningkatkan pemahaman materi polimer melalui penerapan model pembelajaran self organized learning environments (SOLE) siswa kelas X RPL di SMK N 1 Sanden. Penelitian dilakukan di SMK N Sanden, dengan subjek penelitian kelas X RPL. Penelitian ini menggunakan penelitian tindakan kelas, terdiri dari dua siklus dan tiap-tiap siklus terdiri dari tiga pertemuan. Teknik pengumpulan data menggunakan tes. Tes digunakan untuk mengambil data pemahaman materi Polimer. Data pemahaman materi Polimer dianalisis dengan analisis deskriptif kuantitatif. Hasil penelitian menunjukkan bahwa penerapan model pembelajaran self organized learning environments (SOLE) dapat meningkatkan pemahaman materi polimer siswa kelas X RPL di SMK N 1 Sanden dengan langkah-langkah: (1) Question atau Pertanyaan. Guru memberikan pertanyaan ke siswa melalui format yang berisi pertanyaan yang di bagikan melalui WA group. (2) Investigate atau Investigasi. Siswa melakukan investigasi atau pencarian jawaban lewat internet. Jawaban yang telah diperoleh siswa ditulis dibuku, kemudian difoto dan dishare ke WA guru lewat jaringan pribadi. (3) Review atau Mencermati. Guru melakukan review jawaban siswa dengan cara mengunduh jawaban siswa yang dishare lewat jaringan pribadi. Jawaban siswa yang telah direview dikembalikan ke siswa dengan cara difoto lewat WA jalur pribadi siswa. Penerapan model pembelajaran Self Organized Learning Environments (SOLE) dapat meningkatkan pemahaman materi polimer siswa kelas X RPL di SMK N 1 Sanden dari persentase ketuntasan klasikal 57,89\% pada siklus I, menjadi 73,68\% pada siklus II dan telah mencapai indikator keberhasilan penelitian.
\end{abstract}

Kata kunci: Self Organized Learning Environments, polimer, pemahaman.

\section{The application of Self Organized Learning Environments (SOLE) Learning Model to Improve Understanding of Polymer}

\begin{abstract}
This study aims to 1) Obtain an overview of the application Self organized learning environments (SOLE) learning model to improve student's of Grade X RPL SMK N 1 Sanden understanding about polymer material, 2) To improve student's understanding about polymer materials through the application of SOLE learning models. This study used a classroom action research approach, consisting of two cycles, each cycle consisting of three meetings. The data collection technique uses tests, which are used to retrieve data about the materials. It was analyzed using quantitative descriptive analysis. The results showed that the application of SOLE learning model improve student's understanding with the following steps: (1). Questions. Teacher gives questions which are shared through WhatApps group, (2) Investigation. Students carry out investigations for answers through internet, (3) Review. Teacher reviews it by downloading the answers that are shared through WhatApps. Student answers that have been reviewed are returned to students by being photographed through student's private line. The application of SOLE the learning model able to improve student's understanding of polymer material from a percentage of classical completeness of $57.89 \%$ in cycle I to $73.68 \%$ in cycle II and have achieve indicators of the success of the action.
\end{abstract}

Keywords: Self Organized Learning Environments, polimer, understanding.

\section{Pendahuluan}

Pandemi Covid-19 memaksa pembelajaran dilakukan melalui dunia maya yang femiliar dengan sebutan Pembelajaran Jarak Jauh (PJJ) (Kamil, 2020). Penerapan pembelajaran jarak jauh menuntut guru untuk menguasai media pembelajaran yang mendukung dan berbasis IT, serta menguasai metode pembelajaran yang inovatif. Media pembelajaran yang mendukung dan berbasis IT, seperti : Google Classroom, 
WhatsApp, Sismart. Metode Pembelajaran yang inovatif untuk PJJ menurut Adit (2020) ada 6, yakni Discovery-Inquiry, Flipped Classroom, PjBL, Blended Learning, Berbasis Gim, dan SOLE.

Pembelajaran Kimia di SMK N 1 Sanden selama masa pandemi Covid-19 belum menerapkan metode pembelajaran yang inovatif. Metode pembelajaran yang diterapkan di kelas X RPL selama semester gasal tahun pelajaran 2020/2021 sebatas pemberian materi dan penugasan. Setelah diadakan penilaian akhir semester gasal ketuntasan klasikal yang dicapai kelas X RPL hanya mencapai 5,26\%. Hal ini disimpulkan bahwa tingkat pemahaman materi siswa rendah. Kelemahan metode penugasan antara lain karena guru tidak mengawasi langsung, siswa mengirim tugas hanya copy paste dari pekerjaan teman, tugas tidak dikerjakan siswa sendiri melainkan dikerjakan orang lain (Djamarah, 2006: 87).

Untuk mengatasi agar pemahaman materi siswa dapat meningkat meskipun pembelajaran jarak jauh, perlu dicari alternatif model pembelajaran. Model pembelajaran yang inovatif yang diharapkan mampu meningkatkan pemahaman materi siswa, yaitu dengan menerapkan model pembelajaran self organized learning environments (SOLE). Dengan menerapkan model SOLE diharapkan dapat meningkatkan pemahaman materi siswa.

Pemahaman merupakan hasil belajar, misalnya siswa mampu menjelaskan dengan menggunakan kata-katanya sendiri tentang apa yang dibaca atau didengar, serta bisa memberikan contoh lain selain yang disebutkan guru (Sudjana, 1995: 24). Pemahaman berdasrkan Benyamin S Bloom adalah kesanggupan seseorang untuk memahami dan mengerti sesuatu sesudah sesuatu itu dipahami dan diingat. Seorang siswa disebut memahami materi jika ia mampu menjelaskan secara rinci tentang materi tersebut dengan menggunakan bahasa sendiri (Sudijono, 2011: 50). Widoyoko (2014: 31) mengatakan pemahaman adalah makna dari pesan-pesan belajaran yang dikonstruksikan lewat pembelajaran, buku, dan sumber belajar yang lain, baik bersifat lisan, tulisan, atau grafik.

Dari paparan di atas bisa disimpulkan bahwa pemahaman materi ialah kemampuan siswa untuk menjelaskan dengan menggunakan kalimat sendiri dan dapat menyajikan contoh tentang ilmu yang telah diperoleh, baik dari guru, internet, maupun sumber belajar lainnya.

SOLE (self organized learning environments) merupakan model pembelajaran yang awal mula dikenalkan pada tahun 1999 oleh seorang ilmuwan Pendidikan bernama Sugata Mitra. Titik berat dari penerapan model pembelajaran SOLE adalah pembelajaran mandiri yaitu siswa belajar sendiri dengan menggunakan internet dan perangkat pintar yang dimiliki.

Model pembelajaran SOLE dirancang agar bisa membantu guru mendorong siswa pada rasa ingin tahu yang ada dalam dirinya dengan melaksanakan kegiatan pembelajaran berbasis siswa. Pembelajaran berbasis siswa komponennya meliputi rasa ingin tahu, kerjasama, terorganisir sendiri, diikutsertakan, sosial, dan adanya fasilitas berupa motivasi dari orang dewasa (Mitra, 2015).

Langkah-langkah penerapan model pembelajaran SOLE: 1) Question atau Pertanyaan. Guru memberikan pertanyaan, 2) Investigate atau Investigasi. Siswa menginvestigasi pertanyaan dari guru yaitu dengan cara mencari lewat internet atau e-book atau rumah belajar, dan 3) Review atau Pencermatan. Guru mereview hasil investigasi siswa (Sidik, 2020).

Ilmu Kimia merupakan bagian ilmu pengerahuan alam. Yang dipelajari dalam ilmu kimia mencakup wujud zat, sifat zat, struktur zat, perubahan zat, serta energi yang menyertai perubahan zat (Djony, 2019: 3). Subjek kimia yang dipelajari di Kelas X diantaranya adalah Polimer. Pada pembelajaran jarak jauh di era wabah Covid-19, pembelajaran materi polimer diterapkan dengan model pembelajaran SOLE. Dengan menerapkan pembelajaran model SOLE diharapkan dapat meningkatkan pemahaman siswa.

Permasalahan pada penelitian ini bisa dirumuskan seperti berikut: 1) Bagaimana diskripsi penerapan model pembelajaran SOLE untuk meningkatkan pemahaman materi polimer siswa kelas X RPL di SMK N 1 Sanden? 2) Apakah penerapan model pembelajaran SOLE dapat meningkatkan pemahaman materi polimer siswa kelas X RPL di SMK N 1 Sanden?

Tujuan penelitian: 1) Mendeskripsikan penerapan model pembelajaran SOLE untuk meningkatkan pemahaman materi polimer siswa kelas $\mathrm{X}$ RPL di SMK N 1 Sanden, 2) Menguji peningkatkan pemahaman materi polimer melalui penerapan model pembelajaran self organized learning environments (SOLE) siswa kelas X RPL di SMK N 1 Sanden.

Diharapkan hasil penelitian ini bermanfaat, secara: 1) Teoritis: (a) Sebagai sumber acuan atau referensi penelitian yang berikutnya, (b) memperbanyak riset berkenaan hasil penelitian pembelajaran Kimia, (c) Menyumbang bagi 
penambahan khasanah model pembelajaran dalam dunia pendidikan khususnya pada pembelajaran Kimia di SMK. 2) Praktis: (a) Bagi Guru. Guru SMK N 1 Sanden dapat menggunakan hasil penelitian ini untuk rujukan model pembelajaran pada pengembangan pembelajaran formal dengan mengaplikasikan metode pembelajaran yang sesuai sehingga siswa termotivasi dan hasil pembelajaran bisa mencapai hasil yang optimal. Pengalaman secara langsung diperoleh guru. Dari pengalaman tersebut diharapkan mutu pembelajaran dan kompetensi guru bisa meningkat. (b) Bagi siswa. Riset ini merupakan usaha guna meningkatkan pemahaman materi siswa dalam pembelajaran. (c) Bagi sekolah. Dengan diterapkan model pembelajaran SOLE dapat memberikan gagasan/ide untuk sekolah sebagai sarana pembenahan pembelajaran, sehingga berdampak pada pelaksanaan pembelajaran yang semakin mangkus dan bisa menghasilkan pendidikan lebih berkualitas.

\section{Metode Penelitian}

Penelitian ini menggunakan jenis penelitian tindakan kelas. Waktu pelaksananaan penelitian tindakan kelas dari bulan Desember 2020 hingga bulan Maret 2021. Tempat pelaksanaan penelitian tindakan kelas di SMK N 1 Sanden. SMK N 1 Sanden merupakan SMK Negeri di Bantul yang terletak paling selatan dekat dengan pantai selatan yaitu Pantai Samas. Jarak dari Ibu Kota Kabupaten ke SMK N 1 Sanden kurang lebih 20 kilometer ke arah selatan.

Subjek penelitian tindakan kelas ini adalah siswa kelas X Rekayasa Perangkat Lunak, dengan siswa yang berjumlah 19 terdiri 10 siswa laki-laki dan 9 siswa perempuan. Alasan dipilih kelas $\mathrm{X}$ RPL karena persentase ketuntasan klasikal kelas X RPL pada penilaian akhir semester gasal tahun pelajaran 2020/2021 sangat rendah, yaitu $5,26 \%$.

Macam penelitian ini adalah penelitian tindakan kelas yang dilakukan menggunakan siklus tindakan terdiri empat (4) jenjang utama, sebagaimana dikemukakan oleh Arikunto (Arikunto, Suhardjono, Sapardi, 2007:74) yaitu perencanaan, pelaksanaan, obeservasi atau pengamatan, dan refleksi. Penelitian tindakan kelas ini terdiri dari dua (2) siklus, dan masingmasing siklus terdiri dari tiga (3) kali tatap muka. Alur Penelitian Tindakan Kelas seperti tertera pada Gambar 1.

Pada penelitian tidakan kelas ini diterapkan model pembelajaran SOLE untuk meningkatkan pemahaman materi polimer kelas X RPL di SMK $\mathrm{N} 1$ Sanden. Adapun langkah-langkah model pembelajaran SOLE, yaitu ; 1) Pertanyaan. Guru

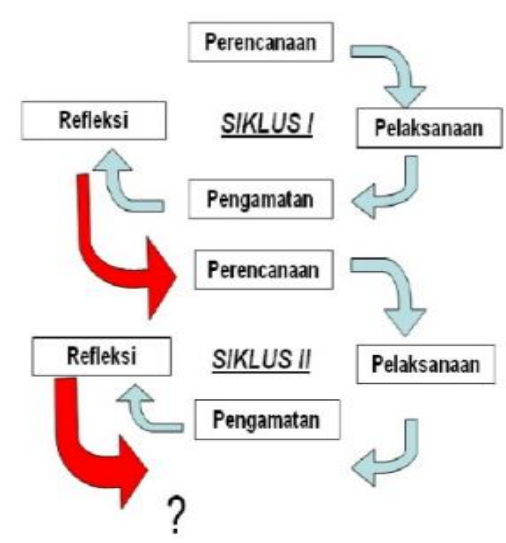

Gambar 1. Alur Penelitian Tindakan Kelas

memberikan pertanyaan pada siswa menggunakan googleform 2) Investigasi. Siswa melakukan investigasi lewat internet. Hasil investigasi siswa diupload pada googleform 3) Review. Guru mereview hasil investigasi siswa, dengan cara mengunduh pekerjaan siswa kemudian dikoreksi dan hasil koreksi dikembalikan kepada siswa dengan cara difoto dan dikirim lewat whatsapp.

Data pemahaman materi polimer siswa dikumpullkan melalui kegiatan Penilaian Harian. Instrumen yang digunakan untuk mengumpulkan data pemahaman materi polimer siswa yaitu berupa tes. Tes yang dipakai berupa soal esai. Tes dipakai guna mengukur pemahaman siswa dari segi kognitif, yaitu melihat sejauh mana siswa memahami materi setelah menerapkan model pembelajaran SOLE.

Untuk mengukur peningkatan pemahaman siswa digunakan perbandingan, yaitu perbandingan nilai rerata kelas penilaian harian pada siklus I dengan nilai rerata kelas hasil penilaian harian pada siklus II. Selain nilai rerata kelas dibandingkan juga persentase ketuntasan klasikal. Teknik analisis datanya menerapkan rumus sebagai berikut:

a) Rerata pemahaman materi polimer siswa kelas X RPL

Keterangan:

$$
\bar{y}=\frac{\sum y_{i}}{n}
$$

$\overline{\mathrm{y}} \quad$ : nilai rerata kelas

$\sum y_{i}$ : jumlah nilai siswa 1 kelas

$\mathrm{n}$ : jumlah siswa

b) Persentase ketuntasan klasikal:

$$
\%=\frac{\sum \text { siswa yang memperoleh nilai } \geq 75}{\sum \text { siswa }} \times 100 \%
$$

Penelitian tindakan kelas ini dinyatakan berhasil jika persentase ketuntasan klasikal pemahaman materi polimer siswa yang didapat dari hasil tes penilaian harian mencapai minimal $70 \%$. 


\section{Hasil dan Pembahasan}

Sebelum dilaksanakan penelitian tindakan kelas, dilakukan langkah awal yang yaitu melihat hasil penilaian akhir semester (PAS) gasal tahun pelajaran 2020/2021. Nilai rerata kelas X RPL pada penilaian akhir semester gasal tahun pelajaran 2020/2021 adalah 53,15, dengan nilai tertinggi 77,00 dicapai oleh 1 siswa dan nilai terendah 15 ada 3 siswa, serta ketuntasan klasikal 5,26 \%. Data hasil penilaian akhir semester gasal tahun 2020/2021 klas X RPL tertera pada Tabel 1. sebagai data kondisi awal.

Tabel 1. Daftar nilai PAS gasal klas X RPL tahun pelajaran 2020/2021

\begin{tabular}{clcl}
\hline No & Kode Subjek & Nilai & Keterangan \\
\hline 1 & AH & 15,00 & Tidak Tuntas \\
2 & ADF & 15,00 & Tidak Tuntas \\
3 & AN & 60,00 & Tidak Tuntas \\
4 & ANR & 77,50 & Tuntas \\
5 & ASN & 47,50 & Tidak Tuntas \\
6 & AIM & 70,00 & Tidak Tuntas \\
7 & EA & 67,50 & Tidak Tuntas \\
8 & FBP & 65,00 & Tidak Tuntas \\
9 & HS & 60,00 & Tidak Tuntas \\
10 & IA & 55,00 & Tidak Tuntas \\
11 & LN & 55,00 & Tidak Tuntas \\
12 & NP & 50,00 & Tidak Tuntas \\
13 & PWN & 52,50 & Tidak Tuntas \\
14 & RJ & 60,00 & Tidak Tuntas \\
15 & RWS & 72,50 & Tidak Tuntas \\
16 & RFI & 15,00 & Tidak Tuntas \\
17 & WEP & 55,00 & Tidak Tuntas \\
18 & YWN & 52,36 & Tidak Tuntas \\
19 & NS & 65,00 & Tidak Tuntas \\
\hline Rerata & 53,15 & \\
\hline \multicolumn{2}{l}{ Ketuntasan Klasikal } & $5,26 \%$ & \\
\hline
\end{tabular}

Hasil tes penilaian harian pada siklus I pertemuan ke-3 dengan soal berbentuk esai jumlah soal ada empat (4), skor maksimal 20, nilai maksimal 100, dan diikuti sejumlah 19 siswa dengan perolehan hasil sebagai berikut. Nilai tertinggi 100 dicapai ole 3 siswa, dan nilai terendah 20 ada 3 siswa. Nilai rerata kelas 65,53 dan persentase ketuntasan klasikal 57,89\%. Nilai Tes Penilaian Harian siklus I pertemuan ke-3 secara lengkap tercantum di Tabel 2.

Hasil tes penilaian harian pada siklus II pertemuan ke-3 dengan soal berbentuk esai jumlah soal ada lima (5) , skor maksimal 25 , nilai maksimal 100, dan diikuti 19 siswa dengan perolehan hasil sebagai berikut. Nilai tertinggi 100 dicapai 5 siswa, nilai terendah 52 dicapai 4 siswa. Nilai rerata kelas 72,05 dan persentase ketuntasan klasikal 73,68.\%. Nilai tes penilaian harian siklus II pertemuan ke-3 selengkapnya tertera pada Tabel 3.
Tabel 2. Nilai tes penilaian harian kelas X RPL siklus I pertemuan ke-3

\begin{tabular}{clll}
\hline No & Kode Subjek & \multicolumn{1}{c}{ Nilai } & Keterangan \\
\hline 1 & AH & 25 & Tidak Tuntas \\
2 & ADF & 80 & Tuntas \\
3 & AN & 80 & Tuntas \\
4 & ANR & 90 & Tuntas \\
5 & ASN & 30 & Tidak Tuntas \\
6 & AIM & 70 & Tidak Tuntas \\
7 & EA & 90 & Tuntas \\
8 & FBP & 20 & Tidak Tuntas \\
9 & HS & 100 & Tuntas \\
10 & IA & 40 & Tidak Tuntas \\
11 & LN & 50 & Tidak Tuntas \\
12 & NP & 80 & Tuntas \\
13 & PWN & 90 & Tuntas \\
14 & RJ & 80 & Tuntas \\
15 & RS & 100 & Tuntas \\
16 & RFI & 20 & Tidak Tuntas \\
17 & WEP & 20 & Tidak Tuntas \\
18 & YWN & 80 & Tuntas \\
19 & NS & 100 & Tuntas \\
\hline Rerata & 65,53 & \\
\hline$\%$ Ketuntasan & $57,89 \%$ & \\
Klasikal & & \\
\hline
\end{tabular}

Tabel 3. Nilai tes penilaian harian kelas X RPL siklus II pertemuan ke-3

\begin{tabular}{|c|c|c|c|}
\hline No & Kode Subjek & Nilai & Keterangan \\
\hline 1 & $\mathrm{AH}$ & 52 & Tidak Tuntas \\
\hline 2 & $\mathrm{ADF}$ & 80 & Tuntas \\
\hline 3 & AN & 52 & Tidak Tuntas \\
\hline 4 & ANR & 100 & Tuntas \\
\hline 5 & ASN & 76 & Tuntas \\
\hline 6 & AIM & 68 & Tidak Tuntas \\
\hline 7 & EA & 56 & Tidak Tuntas \\
\hline 8 & FBP & 52 & Tidak Tuntas \\
\hline 9 & HS & 100 & Tuntas \\
\hline 10 & IA & 80 & Tuntas \\
\hline 11 & LN & 80 & Tuntas \\
\hline 12 & NP & 100 & Tuntas \\
\hline 13 & PWN & 100 & Tuntas \\
\hline 14 & $\mathrm{RJ}$ & 76 & Tuntas \\
\hline 15 & RS & 76 & Tuntas \\
\hline 16 & RFI & 52 & Tidak Tuntas \\
\hline 17 & WEP & 88 & Tuntas \\
\hline 18 & YWN & 76 & Tuntas \\
\hline 19 & NS & 100 & Tuntas \\
\hline \multicolumn{2}{|c|}{ Rerata } & \multicolumn{2}{|l|}{72,05} \\
\hline \multicolumn{2}{|c|}{ Ketuntasan Klasikal } & $73,68 \%$ & \\
\hline
\end{tabular}

Selama pandemi Covid-19 pembelajaran yang diterapkan adalah pembelajaran jarak jauh (PJJ), artinya siswa belajar dari rumah tidak bertatap muka langsung dengan modal adanya jaringan internet. Selama pembelajaran jarak jauh model pembelajaran yang paling sering diterapkan guru yaitu dengan membagi materi dan memberi tugas (penugasan) yang diunggah ke salah satu media Whatsapp atau Sismart. 
Metode penugasan banyak kelemahannya. Kelemahan metode penugasan menurut Djamarah (2006: 236): 1) Kerapkali siswa tidak jujur, siswa hanya mengcopy paste hasil pekerjaan temannya, tanpa ada usaha untuk mengerjakan sendiri, 2) Kadang-kadang tugas dikerjakan oleh orang lain, bisa teman, kakak, bahkan orang tua siswa, 3) Sukar memberikan tugas yang memenuhi perbedaan masing-masing siswa.

Dengan menerapkan metode penugasan tingkat pemahan materi siswa masih relatif rendah, hal ini dapat dilihat dari hasil Penilaian Akhir Semester Gasal Tahun Pelajaran 2020/2021 kelas X RPL. Rerata hasil Penilaian Akhir Semester gasal mencapai 53,15 dan ketuntasan klasikal 5,26\%, artinya dari 19 siswa yang memperoleh nilai di atas atau sama dengan KKM sebanyak 1 siswa (sebagai data awal). Perbandingan persentase antara siswa yang tuntas dengan yang Tidak Tuntas tertera pada Gambar 2 berikut.

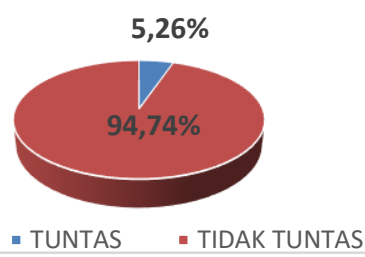

Gambar 2. Diagram ketuntasan klasikal kondisi awal

Untuk mengatasi rendahnya tingkat pemahaman materi siswa perlu dicari model pembelajaran yang menuntut siswa agar belajar mandiri, yaitu dengan menerapkan model pembelajaran self organized learning environment (SOLE).

Pada siklus I pertemuan ke-3 dilakukan tes penilaian harian, yang bertujuan untuk mengukur tingkat pemahaman materi Pengertian, Strutur, dan Tata Nama Polimer siswa setelah diterapkan pembelajaran dengan model pembelajaran SOLE. Nilai rerata tes penilaian harian yang diperoleh 65,53 dan persentase ketuntasan hasil belajar klasikal mencapai 57,89\%. Perbandingan persentase siswa yang tuntas dan belum tuntas pada Siklus I tertera pada Gambar 3 berikut.

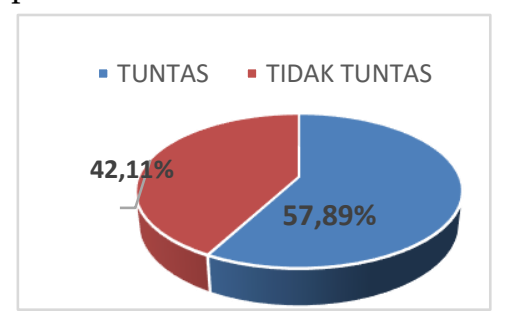

Gambar 3. Diagram ketuntasan klasikal pada siklus I
Nilai rerata hasil tes penilaian harian pada kondisi awal dibanding rerata hasil tes penilaian harian pada siklus I mengalami peningkatan, nilai rerata saat kondisi awal 53,15 sedangkan rerata nilai tes penilaian harian saat siklus I sebesar 65,53 mengalami kenaikan sebesar 12,38. Data nilai rerata pada kondisi awal dan nilai rerata tes penilaian harian pada Siklus I tertera pada Tabel 4.

Tabel 4. Nilai rerata kondisi awal dan pada siklus I

\begin{tabular}{lc}
\hline \multicolumn{1}{c}{ Keadaan } & Nilai Rerata \\
\hline Kondisi Awal & 53,15 \\
Siklus I & 65,53 \\
\hline
\end{tabular}

Perbandingan nilai rerata kondisi awal dan nilai rerata tes penilaian harian pada Siklus I tertera pada Gambar 4 berikut.

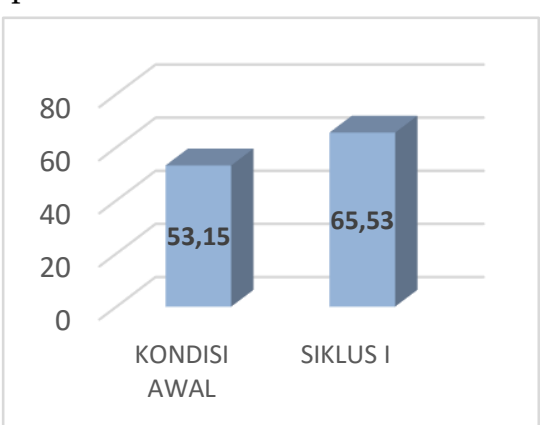

Gambar 4. Grafik perbandingan nilai rerata kondisi awal dengan siklus I

Persentase ketuntasan klasikal saat Kondisi Awal sebesar 5,26\%, persentase ketuntasan klasikal saat siklus I sebesar 57,89 \%. Data persentase ketuntasan klasikal pada Kondisi Awal sebesar dan persentase ketuntasan klasikal tes penilaian harian pada siklus I tertera pada Tabel 5 berikut.

Tabel 5. Persentase ketuntasan klasikan kondisi awal dan pada siklus I

\begin{tabular}{lc}
\hline \multicolumn{1}{c}{ Keadaan } & \% Ketuntasan Klasikal \\
\hline Kondisi Awal & $5,26 \%$ \\
Siklus I & $57,89 \%$. \\
\hline
\end{tabular}

Perbandingan persentase ketuntasan klasikal pada kondisi awal dibanding dengan siklus I mengalami kenaikan, Persentase ketuntasan klasikal pada kondisi awal sebesar 5, $26 \%$ sedangkan persentase ketuntasan klasikal pada tes penilaian harian pada siklus I sebesar $57,89 \%$, sehingga mengalami kenaikan sebesar 52, $63 \%$. Perbandingan persentase ketuntasan klasikal kondisi awal dan siklus I tertera pada tertera pada Gambar 5 berikut. 


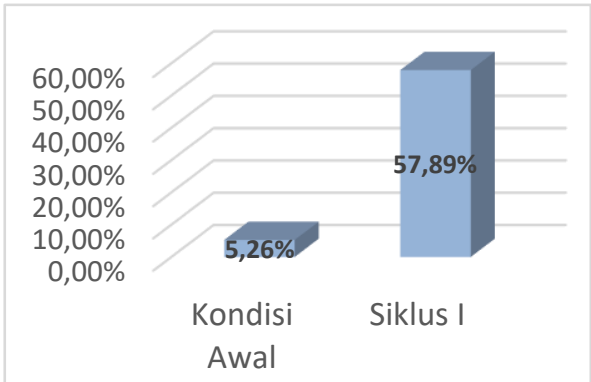

Gambar 5. Grafik perbandingan ketuntasan klasikal kondisi awal dengan siklus I

Berdasarkan hasil dari perbandingan persentase ketuntasan klasikal kondisi awal dengan siklus I terjadi peningkatan yang signifikan yaitu sebesar 52,63\%.

Setelah diterapkan pembelajaran model SOLE pada siklus I, baik nilai rerata kelas maupun persentase ketuntasan klasikal mengalami peningkatan, hal ini membuktikan bahwa dengan diterpkan model pembelajaran SOLE, ada peningkatan pemahaman siswa terhadap materi yang dipelajari.

Pada siklus I Persentase ketuntasan klasikal telah mengalami peningkatan secara signifikan dibanding ketuntasan klasikal kondisi awal, tetapi persentase ketuntasan klasikal yang dicapai pada siklus I belum memenuhi kriteria atau indikator keberhasilan penelitian, sehingga penelitian tindakan kelas perlu dilanjutkan ke siklus berikutnya yaitu siklus II.

Pada siklus II pertemuan ke-3 dilakukan tes penilaian harian, yang bertujuan untuk mengukur tingkat pemahaman materi Polimerisasi, dan Dampak Penggunaan Polimer siswa setelah diterapkan pembelajaran dengan model pembelajaran SOLE. Nilai rerata tes penilaian harian yang diperoleh 72,05 dan persentase ketuntasan klasikal 73,68\%.

Perbandingan persentase siswa yang tuntas dan yang Tidak Tuntas pada siklus II tertera pada Gambar 6 berikut.

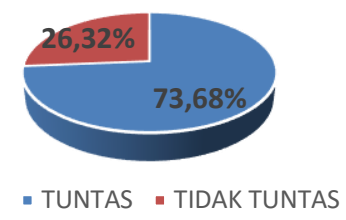

Gambar 6. Grafik perbandingan ketuntasan klasikal siklus II

Nilai rerata hasil tes penilaian harian pada Siklus I dibanding nilai rerata hasil tes penilaian harian pada siklus II mengalami peningkatan. Nilai rerata tes penilaian harian pada Siklus I sebesar 65,53 sedangkan nilai rerata tes penilaian harian pada siklus II sebesar 72,05 mengalami peningkatan sebesar 8,52. Data nilai rerata tes penilaian harian pada Siklus I dan Siklus II tertera pada Tabel 6 berikut.

Tabel 6. Nilai rerata tes penilaian harian pada siklus I dan siklus II

\begin{tabular}{lc}
\hline \multicolumn{1}{c}{ Keadaan } & Nilai Rerata \\
\hline Siklus I & 63,53 \\
Siklus II & 72,05 \\
\hline
\end{tabular}

Nilai rerata tes penilaian harian pada siklus I dibandingkan dengan nilai rerata tes penilaian harian pada siklus II tertera pada Gambar 7.

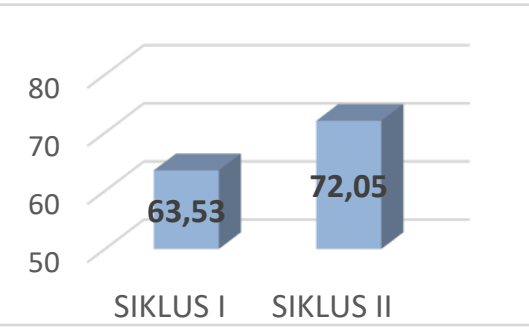

Gambar 7. Grafik perbandingan nilai rerata tes penilaian harian pada siklus I dan siklus II

Berdasarkan hasil perbandingan nilai rerata kelas pada siklus I dan siklus II mengalami kenaikan sebesar 8,52.

Ketuntasan klasikal tes penilaian harian siklus I dan siklus II. Persentase ketuntasan klasikal pada tes penilaian harian pada siklus I sebesar 57,89\%, persentase ketuntasan klasikal pada tes penilaian harian pada siklus II sebesar 73,68\%. Data ketuntasan klasikal tes penilaian harian pada siklus I dan siklus II tertera pada Tabel 7.

Tabel 7. Persentase Ketuntasan klasikal tes penilaian harian pada siklus I dan siklus II

\begin{tabular}{lc}
\hline \multicolumn{1}{c}{ Keadaan } & \% Ketuntasan Klasikal \\
\hline Siklus I & $57,89 \%$, \\
Siklus II & $73,68 \%$ \\
\hline
\end{tabular}

Perbandingan persentase ketuntasan klasikal tes penilaian harian pada siklus I dan siklus II mengalami peningkatan signifikan yaitu sebesar 15,79\%. Perbandingan persentase ketuntasan klasikal tes penilaian harian pada siklus I dan siklus II tertera pada Gambar 8.

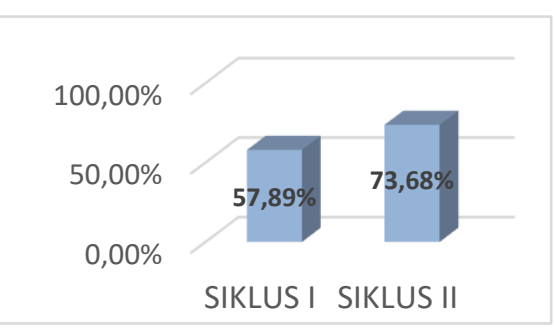

Gambar 8. Grafik perbandingan persentase ketuntasan klasikal tes penilaian harian pada siklus I dan siklus II 
Berdasarkan hasil perbandingan persentase ketuntasan klasikal tes penilaian harian pada siklus I dan siklus II, ketuntasan klasikal pada siklus I sebesar 57,89\% dan ketuntasan klasikal pada siklus II sebesar $73,68 \%$, sehingga mengalami peningkatan sebesar $15,79 \%$.

Setelah dibandingkan nilai rerata tes penilaian harian pada siklus I dan siklus II, serta persentase ketuntasan klasikal pada siklus I dan siklus II, ternyata pada siklus II baik nilai rerata kelas maupun persentase ketuntasan mengalami kenaikan yang signifikan. Faktor penyebab terjadinya peningkatan yang signifikan pada siklus II adalah pada saat investigasi pada siklus I saat investigasi siswa melakukan sendiri (mandiri), sedangkan pada siklus II siswa mengerjakannya secara berkelompok, meskipun tetap lewat dunia maya, yaitu menggunakan Whatsapp kelompok. Dengan dikerjakan secara berkelompok siswa bisa berkolaborasi antar teman. Disamping pelaksanaan investigasi, ada faktor lain yaitu pada siklus I siswa mencari link materi sendiri, sehingga satu kelas sumbernya bisa tidak sama, pada siklus II guru menyediakan beberapa link materi yang bisa langsung diakses oleh siswa.

Penelitian sejenis telah dilakukan oleh Indrayana (2019) dengan judul Bangun Sistem Pembelajaran Model SOLE (Self organized learning environment) Berbasis Web dengan Gaya Belajar Vak untuk Meningkatkan Pemahaman Kognitif Siswa. Indrayana menyimpulkan bahwa sistem pembelajaran model SOLE dapat meningkatkan kemampuan kognitif siswa dari nilai rerata kelas sebesar 46 menjadi 79 .

Pada siklus II disamping mengalami peningkatan dibanding siklus I, persentase ketuntasan klasikal pada siklus II yakni sebesar $73,68 \%$ telah mencapai indikator keberhasilan penelitian Tindakan kelas yang ditetapkan, yaitu sebesar 70\%. Dengan demikian penelitian Tindakan kelas telah dinyatakan berhasil.

Dengan berhasilnya penelitian tindakan kelas yang menerapkan model pembelajaran "self organized learning environment (SOLE)" pada pembelajaran mata pelajaran kimia materi Polimer, guru dapat menggunakan model pembelajaran "self organized learning environment (SOLE)".sebagai salah satu alternatif model pembelajaran untuk meningkatkan pemahaman materi siswa. Model pembelajaran "self organized learning environment (SOLE)" dapat dijadikan sebagai salah salah satu model pembelajaran jarak jauh di era pandemi Covid-19 yang inovatif, berkualitas, dan bermakna di sekolah.

\section{Simpulan dan Saran}

Berdasarkan hasil penelitian dan pembahasan tentang penerapan model pembelajaran SOLE untuk meningkatkan pemahaman materi Polimer siswa kelas X RPL di SMK N 1 Sanden, dapat disimpulkan bahwa : 1) Penerapan model pembelajaran self organized learning environments (SOLE) dapat meningkatkan pemahaman materi polimer siswa kelas X RPL di SMK N 1 Sanden dengan deskripsi sebagai berikut: (1) Question atau Pertanyaan. Guru memberikan Pertanyaan ke siswa melalui format yang berisi pertanyaan di bagikan melalui WA group atau sismart. (2) Investigate atau Investigasi. Siswa melakukan investigasi jawaban lewat internet, Jawaban yang telah diperoleh siswa ditulis dibuku, kemudian difoto dan dishare ke WA guru. (3) Review atau Pencermatan. Guru melakukan review jawaban siswa, Jawaban siswa yang telah direview guru dikembalikan lagi ke siswa. 2) Penerapan model pembelajaran self organized learning environments (SOLE) teruji dapat meningkatkan pemahaman materi polimer siswa kelas X RPL di SMK N 1 Sanden terbukti dengan meningkatnya nilai rerata kelas sebesar 8,52 dari nilai rerata kelas 63,53 pada siklus I menjadi 72,05 pada siklus II, ketuntasan klasikal pada siklus I sebesar $57,89 \%$ meningkat menjadi $73,68 \%$ pada siklus II.

Bertolak dari kesimpulan dan pembahasan pada penelitian ini, maka disarankan pada guru untuk menerapkan model pembelajaran self organized learning environment (SOLE) pada pembelajaran jarak jauh diera pandemi Covid-19. Pada saat menerapkan model pembelajaran SOLE pada siklus I, dijumpai kendala ketidakseragaman sumber belajar dan tidak ada kerjasama antar siswa. Oleh karena itu, peneliti berikutnya disarankan untuk mengantsipasi kendala tersebut.

\section{Daftar Pustaka}

Adit, A (2020). Bosan PJJ Itu-itu Saja? Ini 6 Model Pembelajaran Inovatif bagi Siswa. Tayang: Kompas.com - 28/08/2020, 11:45 WIB https://www.kompas.com/edu/read/2020/ 08/28/114509371/bosan-pji-itu-itu-sajaini-6-model-pembelajaran-inovatif-bagisiswa?page $=$ all.

Arikunto, S, Suhardjono, Supardi. (2007). Penelitian Tindakan Kelas. Jakarta: Bumi Angkasa

Indrayana, D (2019). Rancang Bangun Sistem Pembelajaran Model SOLE (Self organized learning environment) Berbasis Web dengan Gaya Belajar Vak untuk Meningkatkan Pemahaman Kognitif Siswa. Skripsi. 
Bandung: FMIPA Universitas Pendidikan Indonesia.

Djamarah, SB dan Zain, A. (2006). Strategi Belajar Mengajar. Jakarta: Rineka Cipta.

Djony, S, Naqiyah, S, dan Abidin, Z. (2019). Kimia c1 untuk SMK/MAK Kelas X. Jakarta: Erlangga.

Kamil, I. (2020). Kilas Balik Pembelajaran Jarak Jauh akibat Pandemi Covid-19. Kompas.com03/09/2020.

https://nasional.kompas.com/read/2020/0 9/03/10063201/kilas-balik-pembelajaranjarak-jauh-akibat-pandemi-covid19 ? page $=$ all

Mitra, S. (2015). Self-Organised Learning Environment (SOLE) Toolkit. https://s3-eu- west-1.amazonaws.com/school-in-the-cloudproduction-

assets/toolkit/SOLE_Toolkit_Web_2.6.pdf

Sidik, D. (2020). Pembelajaran Daring dengan Menggunakan Model SOLE (Self Organized Learning Environments). PembaTIK. Pusdatik Kemendikbud: rumah belajar. https://youtu.be/xTUinHlOhTY)

Sudijono, A. (2011). Pengantar Evaluasi Pendidikan. Jakarta: Rajawali Pers.

Sudjana, N. (1995). Penilaian Hasil Proses Belajar Mengajar. Bandung: Remaja Rosdakarya

Widoyoko, E P. (2014). Teknik Penyusunan Instrumen Penelitian. Yogyakarta: Pustaka Pelajar. 